\title{
Phytochemical Analysis of Leaf Extracts of Calophyllum inophyllum L. And Cananga odorata (Lam.) Hook.F. \& Thomson
}

\author{
${ }^{1}$ Isaivani Indrakumar, ${ }^{2} \mathrm{~V}$ Selvi, ${ }^{3} \mathrm{R}$ Gomathi, ${ }^{4} \mathrm{~S}$ Karpagam \\ ${ }^{1,2,3}$ Research scholar, Dept of Botany Queen Mary's College (Autonomous), Mylapore, Chennai 600 004, India \\ ${ }^{4}$ Associate Prof., Dept of Botany Queen Mary's College (Autonomous), Mylapore, Chennai 600 004, India
}

\begin{abstract}
Herbal medicine represents one of the most important fields of traditional medicine all over the world. The medicinal value of plants lies in some chemical constituents which produce a definite physiological action in the human body. The aim of the present study was to find out the nature of bioactive chemical constituents present in methanolic, petroleum ether and chloroform extract of Calophyllum inophyllum and Cananga odorata. A qualitative phytochemical analysis was carried out. Phytoconstituents isolated from various extracts give us clue for further investigation.
\end{abstract}

Key Words: Alkaloids, Extracts, Flavanoids, Calophyllum inophyllum, Cananga odorata

\section{Introduction}

World plant biodiversity is the largest source of herbal medicine; still $60-80 \%$ of the world population rely on plant based medicines which are being used since the ancient ages as traditional health care system. Medicinal plants are of great importance to the health of individuals and communities [1]. Phytoconstituents are the natural bioactive compounds found in plants. These phytoconstituents work with nutrients and fibers to form an integrated part of defense system against various diseases and stress conditions. Phytochemicals are basically divided into two groups, viz; primary and secondary constituents; according to their functions in plant metabolism. Primary constituents comprise of sugars, amino acid, proteins and chlorophyll while secondary constituents consist of alkaloids, terpenoids, saponins, phenolic compounds, flavonoids, tannins and so on. The most important bioactive compounds are flavonoids, alkaloids, glycosides, tannins and phenolic compounds. The phytochemical research based on ethno-pharmacological information is generally considered as an effective approach in the discovery of new anti-infective agents from higher plants [2]. Medicinal plants are generally used in traditional medicine for the treatment of many ailments [3], [4].

Cananga odorata is a fast-growing tree of the family, Annonaceae, that attains an average height of $12 \mathrm{~m}$. It grows in full or partial sun, and prefers the acidic soils of its native rainforest habitat. The evergreen leaves are smooth and glossy, oval, pointed, with wavy margins, and $13-20 \mathrm{~cm}$ long. The flower is drooping, long-stalked, with six narrow greenish yellow tepals, and yields a highly fragrant essential oil. It is used for asthma, malaria, fever, cholera, typhoid, scabies, dermatitis, ulcer and wounds. The seeds are used for stomach complaints with fever and in Indonesia the bark is used for scabies. In Malaysia, a paste of fresh flowers is applied to the chest for asthma and to treat malaria. In Solomon islands, a paste of fresh flowers is applied to boils while in India, the essential oil from the flowers makes an external remedy for cephalgia, opthalmia and gout [5].

Calophyllum inophyllum is a low-branching and slow-growing tree of the family Guttiferae. It usually reaches 8 to 20 metres in height. The flower is 25 millimetres wide and occurs in racemose or paniculate inflorescences consisting of 4 to 15 flowers. Flowering can occur year-round, but usually two distinct flowering periods are observed, in late spring and in late autumn. The fruit (the ballnut) is a round, green drupe reaching 2 to 4 centimetres in diameter and having a single large seed. When ripe, the fruit is wrinkled and its color varies from yellow to brownish-red. The tree is believed to have diuretic properties. The gum extracted from the plant is emetic and purgative and is used for the treatment of wounds and ulcers. An infusion of gum, bark and leaves is used for sore eyes. The leaves soaked in water are applied to inflamed eyes. The leaf infusion is taken internally for heatstroke [5]. The plant has anti-inflammatory and pain relieving properties

\section{Materials And Methods}

2.1 Collection of Plant materials

The leaves of Cananga odorata and Calophyllum inophyllum were collected from Avenues of Teynampet, Chennai. The plant was authenticated at Plant Anatomy Research Centre (PARC) Tambaram, Chennai. The leaves were shade dried for about 15 days and powdered using an electric blender. 
+Fifty gram of the plant powder was loaded in the thimble of Soxhlet apparatus. It was fitted with appropriate size round bottom flask with $250 \mathrm{ml}$ each of Petroleum ether, Chloroform and Methanol, and upper part was fitted with condenser. Constant heat was provided by Mantox heater for recycling of the solvent. After complete extraction, the extract in round bottom flask was transferred into clean and pre-weighed universal tubes. Universal tubes containing extracts were weighted and noted down and finally, the percentage yield was calculated. Percentage yield was calculated as dividing initial weight of raw material taken by final weight of extract. The extract was refrigerated at $5^{\circ} \mathrm{C}$ until required for use.

$\%$ yield of the extract was calculated using the following equation:

$\%$ yield = wt. of crude extract/wt. of dried plant $x 100$

\section{2..3 Phytochemical screening}

Phytochemical examinations were carried out for all the extracts as per the standard methods.

Detection of alkaloids (Mayer's Test, Wagner's Test, Dragendroff's Test, Hager's Test), carbohydrates (Molisch's Test, Benedict's Test, Fehling's Test ), glycosides (Modified Borntrager's Test), saponins (Froth Test, Foam Test), phytosterols (Salkowski's Test, Libermann Burchard's Test), tannins (Ferric Chloride Test, Lead Acetate Test), proteins and aminoacids (Xanthoproteic Test, Ninhydrin Test), flavonoids (Ferric Chloride Test, Alkaline Reagent Test) were carried out by Trease and Evans method.,1978[12]. Detection of steroids, anthraquinones, phlobatannins were carried out by Harbone., 1973[6]. Detection of diterpenes (Copper acetate Test), phenols and coumarins, were carried out by the method of Mace.,1963[9].

\section{Result \& Discussion}

The phytochemicals were separated from dried leaf powder using methanol, petroleum ether and chloroform which showed the presence of many bioactive compounds in the plants selected. In the three forms of extract, fourteen bioactive constituents were observed. Out of these ten were present in the methanolic extract. The results proved the presence of medicinally active compounds in these two plants. From Table 1, Alkaloids, Carbohydrates, Glycosides, Saponin, Phenols, Tannins, Flavanoids, Proteins, steroids and coumarins were present in both plants while phytosterols and diterpenes were absent. But Carbohydrates and saponins were observed in petroleum ether and chloroform extracts of $C$. odorata and $C$. inophyllum. Presence of tannins suggests the ability of this plant to play a major role as antidiarrhoea and antihaemorrhagic agent [6]. Saponin compound has been shown to have immense significance as antihypercholesterol, hypotensive and cardiac depressant properties [7, 8]. Among the three extracts methanolic extracts yield about $71.42 \%$ in C.odorata and 74.44\% in C.inophyllum whereas Petroleum ether extract yield was 21.42 and 23.20 in C.odorata and C.inophyllum and Chloroform produce $14.28 \%$, and $13.60 \%$ in C.odorata and C.inophyllum respectively (Table 2) which clearly proved that the methanolic extracts were the best solvents to extract active constituents present in the plant extracts as compared to petroleum ether and chloroform (Fig. 1).

Steroids and phlobatannins were found to be present in all the plants. It has been found that these plants contain only steroidal compounds. It should be noted that steroidal compounds are of immense importance and the interest in pharmacy is due to their relationship with such compounds as sex hormones [9]. Thus, the plants under investigation showed medicinal potential and can be a source of useful drugs. Further studies are going on in these plants in order to isolate, identify, characterize and elucidate the structure of the bioactive compounds.

The results suggested the presence of constituents which are known to exhibit medicinal as well as physiological activity [10]. Calophyllum inophyllum and Cananga odorata were acidic having phenolic groups which could be attributed to the presence of tannins. Tannins are soluble in water and the presence of alkaloids gives a bitter taste. Glycosides have been known to lower blood pressure, although some workers have attributed the cardiac action of these oils to the presence of the alkaloid, carpaine [11]. The presence of phenolic compounds gave acidic properties and could possibly be responsible for the antimicrobial activities.

TABLE 1: Phytochemicals of leaf extracts of Cananga odorata and Calophyllum inophyllum

\begin{tabular}{|l|c|c|c|c|c|c|}
\hline \multirow{2}{*}{$\begin{array}{c}\text { PHYTOCONST } \\
\text { ITUENS }\end{array}$} & \multicolumn{3}{|c|}{ C.odorata leaf extracts } & \multicolumn{3}{c|}{ C.inophyllum leaf extracts } \\
\cline { 2 - 7 } & Methanol & Petroleum ether & Chloroform & Methanol & Petroleum ether & $\begin{array}{l}\text { Chlorofor } \\
\mathrm{m}\end{array}$ \\
\hline Alkaloids & + & - & - & + & - & - \\
\hline Carbohydrates & + & + & + & + & + & + \\
\hline Glycosides & + & - & - & + & - & - \\
\hline Saponin & + & + & + & + & + & + \\
\hline Phytosterols & - & - & - & - & - & - \\
\hline Phenols & + & - & - & + & - & - \\
\hline Tannins & + & - & - & + & - & - \\
\hline
\end{tabular}


Phytochemical Analysis Of Leaf Extracts Of Calophyllum Inophyllum L. And Cananga Odorata

\begin{tabular}{|l|c|c|c|c|c|c|}
\hline Flavonoids & + & - & - & + & - & - \\
\hline $\begin{array}{l}\text { Proteins \& } \\
\text { Amino acids }\end{array}$ & + & + & - & + & + & - \\
\hline Diterpenes & - & - & - & - & - & - \\
\hline Steroid & + & - & - & + & - & - \\
\hline Anthroquinione & - & - & - & - & - & - \\
\hline Phlobatanins & - & - & - & - & - & - \\
\hline Coumarin & + & - & - & + & - & - \\
\hline
\end{tabular}

$+=$ Presence, $-=$ Absence

TABLE 2 Yield Percentage of Different Solvent Extraction Methods

\begin{tabular}{|c|c|c|c|}
\hline S. No & Solvents & $\begin{array}{c}\text { Percent Yield of } \\
\text { C.odorata leaf extract }\end{array}$ & $\begin{array}{c}\text { Percent Yield of } \\
\text { C.inophyllum leaf extract }\end{array}$ \\
\hline 1. & Methanol & 71.42 & 74.44 \\
\hline 2. & Petroleum Ether & 21.42 & 23.20 \\
\hline 3. & Chloroform & 14.28 & 13.60 \\
\hline
\end{tabular}

Fig 1 Extract Values of C. odorata and C. inophyllum

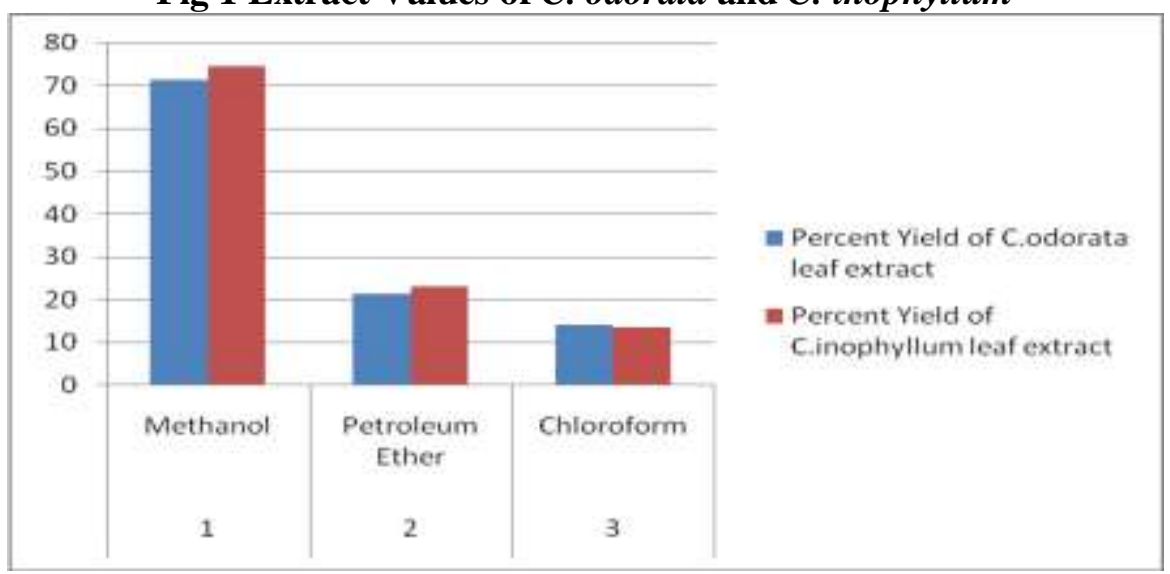

IV. Conclusion

The presence of medicinally bio active constituents in the two plants were analysed. The phytochemical compounds identified in this study were earlier been proved as bioactive. The presence of some of these compounds have been confirmed previously to have medicinal and physiological activity. The selected plant leaves are the potential source to produce drugs. The traditional medicinal plant like these are the excellent feedstock for antimicroabial drug manufacturing. Further, research will explore many kinds of bioactive antimicrobial compounds.

\section{References}

[1] A. Sofowora, Medicinal Plants and Traditional Medicine in Africa. Spectrum Books Ltd., Ibadan, Nigeria, 1993, pp 191-289.

[2] C. E. Ogukwe, E. E. Oguzie, C. Unaegbu, B. N. Okolue, Phytochemical screening on the leaves of Sansevieria trifasciata, J. Chem. Soc. Nigeria, 29(1), 2004, pp 8-10.

[3] C. K. Kokate, Pharmacognosy. 16th Edn, 2001, Nirali Prakasham, Mumbai, India.

[4] D. E. Okwu, Evaluation of the chemical composition of indigenous spices and flavouring Agents. Global J. Pure Appl. Sci. 7(3), 2001, pp 455-459.

[5] H. O. Edeoga, D. E. Okwu and B. O. Mbaebie BO, Phytochemical constituents of some Nigerian medicinal plants, Afr. J. Biotechnol. 4(7), 2005, pp 685-688.

[6] Harborne JB (1973). Phytochemical Methods. Chapman and Hall Ltd., London pp. 49-188.

[7] J. M Watt and M. G Breyer-Brandwyk MG, Medicinal and Poisonous Plants of Southern and Eastern Africa. E. \& S. Livingstone Ltd., London, 1984, pp 105-106.

[8] K. R. Price, T. I. Johnson and G. R. Fenwick, (1987). The Chemistry and Biological Significance of Saponins in Food and feeding stuffs. Crit Rev Food Sci Nutr 26, 1987, pp 22-48

[9] Mace M.E.Phytochenistry ,1963,16,pp 915-925.

[10] P. C. Njoku and A. U. Ezeibe, Phytochemical and elemental analyses of Helianthus annus and its use as blood clotting agent. J. Chem. Soc. Niger. 32(2), 2007, pp 128-132.

[11] T. N. Asquith and L. G. Butler, Interaction of condensed Tannins with selected proteins. Phytochemistry 25 (7), 1986, $1591-1593$.

[12] Trease GE, Evans WC (1978). Pharmacology 11th Ed. Bailliere Tindall Ltd, London. 1978, pp 60-75.

[13] V. Duraipandiyan, M. Ayyanar and S. Ignacimuthu, 2006. Antimicrobial Activity of Some Ethnomedical Plants Used by Paliyar Tribe from Tamil Nadu, India. BMC complementary and alternative medicine, 2006, pp 635. 